\title{
RESENHA
}

CUNHA, Maria Teresa Santos; SOUZA, Flávia de Freitas. Viver e escrever: cadernos de escritas ordinárias de um professor catarinense (Sec XX). Florianópolis: Insular, 2015.

\section{REIVENÇÕES DE SI: ACERVOS PESSOAIS E O USO DE ESCRITAS ORDINÁRIAS COMO FONTES PARA PRODUÇÃO HISTÓRICA}

\author{
Letícia Vieira \\ Doutoranda/PPGE/FEUSP \\ leeevieira@hotmail.com
}

"Viver e Escrever: cadernos de escritas ordinárias de um professor catarinense (Sec XX)", obra de autoria de Maria Teresa Santos Cunha e Flávia de Freitas Souza, transcende o propósito de apresentar o acervo pessoal de um educador ${ }^{1}$, configurando-se como escrito de base por trazer à cena estudos acerca dos cadernos e colocar em pauta a questão das escritas ordinárias enquanto testemunhos de construções de si. A relevância de estudos que se dediquem ao debate teórico do uso deste suporte de escrita enquanto fonte para produção histórica deve-se, sobretudo, à crescente incorporação dessas questões às pesquisas nas áreas de educação e história da educação, o que, segundo as autoras, sinaliza "para uma progressiva introdução da cultura escrita e da mentalidade letrada no acadêmico" (CUNHA; SOUZA, 2015, p. 17). O crescente aumento do uso acadêmico destes artefatos deve vir, por sua vez, acompanhado de discussões que coloquem em evidência suas especificidades e os inúmeros sentidos de que são impregnados, tarefa com a qual a obra em análise contribui significativamente. A narrativa, dividida em duas principais partes, possui um fragmento inicial, de caráter introdutório, onde Maria Teresa Santos Cunha situa a obra, escrita a quatro mãos, no campo da História da Educação e da Leitura, e fornece ao leitor informações básicas sobre o intelectual a quem pertenceu este acervo, o professor catarinense Victor Márcio Konder. O debate e adensamento teórico do estudo dá-se nos dois capítulos seguintes da obra, denominados "Cadernos de um professor catarinense" e "Escritas avulsas, escritas para a história: o acervo de cadernos do professor Marcio Victor Konder (1925-2005)”.

Composto por quarenta e cinco cadernos manuscritos produzidos e utilizados entre as décadas de 1960 e 1980, o acervo de cadernos deste intelectual fora categorizado a partir de sua trajetória, sendo dividido entre cadernos em que este figura como aluno e cadernos nos quais figura como professor. Aliado à explanação dos processos de restauro, organização e

\footnotetext{
${ }^{1}$ A coleção de Victor Konder é composta por 560 livros e 45 cadernos de anotações. A obra em análise destinase, contudo, apenas à análise dos cadernos que a integram.
} 
salvaguarda do material, Cunha e Souza (2015) levam-nos a uma viagem a este acervo, compondo com detalhes a documentação que o integra e agregando à análise do material organizado uma riqueza de imagens e adjetivações. Existe, contudo, ligado a esta questão, um aspecto a ser revisto: por se tratar de uma obra que destina atenção a aspectos da escrita e seus suportes materiais, a diagramação do livro comete alguns pequenos deslizes no que se refere à disposição de imagens, tendo em vista que, algumas delas, sobretudo àquelas que retratam páginas dos cadernos de Konder, não são impressas em resolução que permita ao leitor decifrar os códigos escritos destas linhas grafadas. De outra parte, merece também destaque desta vez, contudo, positivo -, o fato de que a maior parte das páginas do livro guardam um grande espaço de margem, aspecto que, pensado ou não pelas autoras para esta finalidade, concede ao leitor um grande espaço de intervenção e de produção de suas próprias marcas de subjetividade.

Ao tomar por objeto de análise a coleção de cadernos deste intelectual, este estudo volta também atenções à organização gráfica da produção escrita de Victor Konder, identificando-se, nas páginas escritas, ora um norteamento dado a partir da lógica própria do ambiente e noções de tempo das instituições de ensino, ora delineado por uma organização própria do autor. No que se refere a esta última, ressalta-se que o espaço reservado às linhas textuais era também ocupado por desenhos, em sua maior parte perfis de homens, e anotações de cunho político, fato apontado por Cunha e Souza (2015) como indicativo de uma apropriação da tecnologia da palavra por parte do autor - característica típica, segundo elas, daqueles que exercem atividades ligadas ao pensamento. $\mathrm{O}$ caderno, portanto, ainda que formulado para cumprir função de artefato de uso protocolar, configura-se, para as autoras, na medida em que abre espaço para estas "transgressões" por parte do usuário, também como campo de apropriação.

As diversas modalidades textuais que habitam os cadernos da coleção Konder, além de permitirem a identificação dos espaços de transgressão - que, assim como no cotidiano, são criados, por quem escreve, nos suportes de escrita -, contribuem para a melhor compreensão dos processos educativos. Nesta direção, fica evidente, portanto, o fato de que estes suportes, frutos da cultura escolar, figuram como material de valor ímpar, tanto para estudo da produção, circulação e uso dos suportes da escrita escolar, quanto das práticas educativas, currículos e história das disciplinas escolares. Em resumo, conforme muitíssimo bem definido pelas autoras, os cadernos cumprem também a função de dispositivos iluminadores da dinâmica e da interação escolar. Além disso, mais do que lançar luz e revelar 
os traços de apropriação do aluno para com os conteúdos e lógica escolares, revelam resquícios de sua subjetividade - estes últimos encontrados, sobretudo, nos registros marginais -, motivo pelo qual podem receber, também, os cadernos, a denominação de "vetores de construção de subjetividade"2.

Entendidos pelas autoras como locais de construção de uma "memória coesa e edificada de si", os acervos pessoais, quando estudados, revelam questões profundas sobre àqueles que os produzem, permitindo, a quem os analisa, a compreensão do universo social em que seus produtores se encontravam situados - suas redes de sociabilidades e trajetórias de vida, por exemplo. No caso específico do acervo pessoal de Victor Konder, a análise de conteúdo permitiu às autoras o traçar do perfil deste leitor, bem como a compreensão das obras por ele lidas, e a apreensão de traços de sua atuação profissional e de questões ligadas à sua figura de intelectual, exercendo, esta coleção de cadernos, o papel de "observatório dos conteúdos" apropriados por Konder no decorrer de trajetória social.

Evidenciadas as múltiplas possibilidades de interrogação e interpretação que o estudo de cadernos e acervos pessoais possibilitam ao pesquisador, fica, ao historiador, a tarefa de, tendo acesso a esta "sensibilidade" (VIDAL, 2007) própria de dado espaço-tempo, conectar os níveis micro e macro social, compreendendo suas possíveis articulações. A dimensão subjetiva dos cadernos escolares e as múltiplas questões inerentes à análise deste suporte de escrita, faz com que as autoras convidem-nos a atentar à importância do debate acerca das relações entre história e memória. Nesta direção, tomando de empréstimo as palavras de Ângela de Castro Gomes, Cunha e Souza (2015) afirmam que a inquirição dos cadernos, de forma isolada, deve ser feita a partir do olhar de quem o registrou, não devendo, o pesquisador, ter a pretensão de revelar uma construção do passado - devendo este, contudo, manter intenções de verossimilhança.

A obra convida-nos ao debate acerca dos novos paradigmas de pesquisa. Leva-nos a atentar à estes documentos, "portadores de ressonâncias", e aos rastros que habitam cada espaço destes enquanto suportes de escrita. Informa-nos, simultaneamente, acerca de uma série de estudos que têm contribuído com o adensamento das discussões advindas do campo da História da Educação e da Literatura, motivo pelo qual é, esta publicação, digna de friso. Sua iniciativa possibilita a uma infinidade de leitores, sejam eles envolvidos com a educação, com a história, ou, ainda, com o ramo híbrido da história da educação, o contato com estudos de ponta e que colocam ao pesquisador o desafio de trabalhar com uma variação de fonte

\footnotetext{
${ }^{2}$ Noção tomada de Menezes (1998) pelas autoras.
} 
relativamente nova para os profissionais pertencentes a estes campos de pesquisa, fornecendo, para tal, subsídios para os primeiros passos na direção de um embasamento teórico denso. Àqueles que pretendem embarcar na aventura de decifrar a sensibilidade das escritas ordinárias, fica, portanto, o convite à leitura desta consistente e instigante obra. 